\title{
Professor Ângelo Machado: career, scientific contributions, and the iconic neuroanatomy book
}

\author{
Professor Ângelo Machado: carreira, contribuições científicas e o icônico livro de \\ neuroanatomia
}

\author{
Alex Tiburtino MEIRA', Gustavo Leite FRANKLIN², Francisco CARDOSO ${ }^{3}$, Hélio Afonso Ghizoni TEIVE ${ }^{4}$, \\ Orlando Graziani Povoas BARSOTTINI ${ }^{5}$, José Luiz PEDROSO ${ }^{5}$
}

\begin{abstract}
Professor Ângelo Barbosa Monteiro Machado (May 22, 1934 to April 6, 2020) was one of the most outstanding and respected professors in the Brazilian history. He worked broadly as a professor, neuroscientist, writer, dramaturgist, neurobiologist, and entomologist. The publication of the neuroanatomy book is pioneer, revolutionary, and iconic in the history of academic medical education in Brazil. In the literature field, he also wrote many books in which he adapted scientific knowledge to children. In this article, the authors approach the academic life of Professor Ângelo Machado and the steps that culminated in the most renowned Brazilian textbook of neuroanatomy: Neuroanatomia Funcional.
\end{abstract}

Keywords: Neuroanatomy; Neurobiology; Textbook; Faculty.

\section{RESUMO}

O professor Ângelo Barbosa Monteiro Machado (22/05/1934-06/04/2020) foi um dos mais destacados e respeitados professores da história do Brasil. Ele trabalhou amplamente como professor, neurocientista, escritor, dramaturgo e entomologista. A publicação do livro de neuroanatomia é pioneira, revolucionária e icônica na história da educação médica acadêmica no Brasil. No campo da literatura, também escreveu diversos livros nos quais adaptou o conhecimento científico para as crianças. Neste artigo, os autores abordam a vida acadêmica do professor Ângelo Machado e as etapas que culminaram no mais conceituado livro brasileiro de neuroanatomia: Neuroanatomia Funcional.

Palavras-chave: Neuroanatomia; Neurobiologia; Livro-Texto; Docentes.

\section{INTRODUCTION}

Ângelo Barbosa Monteiro Machado was born on May 22, 1934 in Belo Horizonte, Minas Gerais, Brazil'. Since childhood, Ângelo Machado demonstrated all the characteristics of a born scientist. His curiosity and greed for knowledge drew the attention of his family, who set up a laboratory for him in the backyard of their house equipped with a microscope, aquarium, dissection material, and all the books he wanted to buy (personal communication). He graduated in Medicine at the Universidade Federal de Minas Gerais (UFMG) in 1958, for which he later dedicated 67 years of beloved work ${ }^{1}$. His academic life can be divided into two periods: the first as professor and neuroscientist, which resulted in his masterpiece, the book Neuroanatomia Funcional, ${ }^{2,3}$, and the second as the professor of entomology at the same institution. He was married to Conceição Ribeiro da Silva Machado (1936-2007) - his "major scientific discovery" as he stated, with whom he shared not only a life of love and partnership but also an academic life, which resulted in the creation of the Neurobiology Laboratory at the UFMG ${ }^{1,2,4}$. Professor Machado was one of the most respected professors in the history of Brazil, and whose expertise spanned a substantial number of subject areas. He died on April 6, 2020.

\footnotetext{
¿Universidade Federal da Paraíba, Departamento de Medicina Interna, Serviço de Neurologia, João Pessoa PB, Brazil.

²Pontifícia Universidade Católica, Departamento de Medicina Interna, Curitiba PR, Brazil.

${ }^{3}$ Universidade Federal de Minas Gerais, Hospital das Clínicas, Departamento de Medicina Interna, Serviço de Neurologia, Belo Horizonte MG, Brazil.

«Universidade Federal do Paraná, Hospital de Clínicas, Departamento de Medicina Interna, Serviço de Neurologia, Curitiba PR, Brazil.

5Universidade Federal de São Paulo, Departamento de Neurologia, São Paulo SP, Brazil.

ATM (iD) https://orcid.org/0000-0002-6685-7491; GLF (ID) https://orcid.org/0000-0002-0207-3671; FC (iD) https://orcid.org/0000-0003-0808-0116; HAGT (iD) https://orcid.org/0000-0003-2305-1073;0GPB (iD https://orcid.org/0000-0002-0107-0831; JLP (D) https://orcid.org/0000-0002-1672-8894 Correspondence: Alex Tiburtino Meira; Email: alex.m.meira@gmail.com.

Conflict of interest: There is no conflict of interest to declare.

Authors' contributions: ATM, JLP: conceptualization, data curation, formal analysis, investigation, methodology, resources, supervision, validation, visualization, writing-original draft, writing review and editing; GLF, FC, HAGT, OGPB: formal analysis, methodology, project administration, validation, visualization, writing review and editing.

Received on May 02, 2021; Received in its final form on July 06, 2021; Accepted on July 27, 2021.
} 
Several Brazilian associations, such as the Brazilian Academy of Neurology (ABN), the Brazilian Society for the Progress of the Science, the Federal Council of Biology, and the Brazilian Society of Pediatric Neurosurgery, among others, mourned the death of the polymath of the contemporary era.

\section{CAREER}

During high school, Professor Machado had done an internship at the Osvaldo Cruz Foundation, between 1951 and 1956, with the pathologist Lobato Paraense, with whom he also worked later during the medical course. He considers that he started his career as a scientist at that institute. He had also been working as a trainee in the Anatomy Department of School of Medicine at UFMG. Although he had been graduated in Medicine at UFMG in 1958, he had never practiced as a physician ${ }^{2}$. He immediately started his lectures at the Anatomy Department, exerting good influence over medical students and becoming renowned for his remarkable didactic skills and his iconoclastic and sarcastic sense of humor ${ }^{2,5}$. In some of his jokes, when he was asked why he was interested in the pineal gland, he used to answer "my professor of Anatomy thought some weird field I should research for: the pineal gland of the armadillo. So, I did, then I discovered that the armadillo doesn't have pineal gland." He chose the neuroscientific field by noticing that it has been a potential area for research (Figure 1A); he transformed a neglected subject into a new and independent discipline at UFMG,

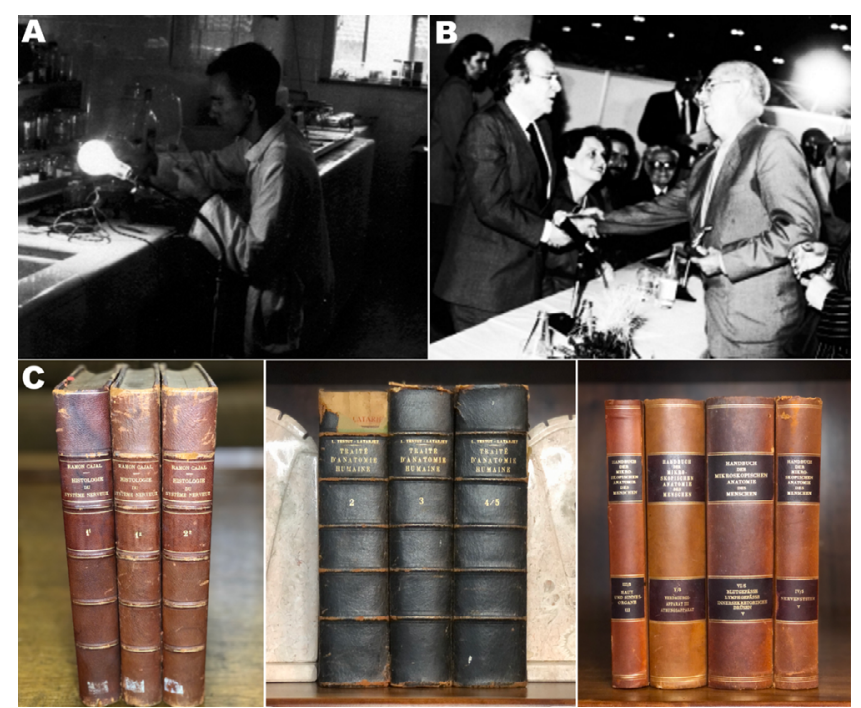

Figure 1. Professor Ângelo Machado. (A) Researching in the Anatomy Department of the School of Medicine, Universidade Federal de Minas Gerais, Brazil, in 1957. (B) Receiving the prestigious "Jabuti Literature Award" in 1993. (C) Some of the books in Angelo Machado's library, which were used to prepare his classes (from left to right: Ramon y Cajal S., Histologie du système nerveux de l'homme \& des vertébrés; Testut L. and Latarjet A., Traité d'anatomie humaine; Handbuch der mikroskopischen Anatomie des Menschen. with great repercussion in its teaching (personal communication). His main contribution to the neurobiological field had been the formation of norepinephrine containing synaptic vesicles by this time ${ }^{5}$. In 1963, he defended his Ph.D. thesis in Anatomy at the UFMG, and, 4 years later, his postdoctorate at the Northwestern University, Chicago (where he lived for 2.5 years) ${ }^{6}$. There, he and his wife learned histochemical techniques for identifying catecholaminergic pathways and neurons and electron microscopy techniques, which later culminated in the creation of the UFMG electron microscopy laboratory and made them pioneers in the study of catecholaminergic pathways with several contributions to the study of the autonomic nervous system. He had taught as a professor of neuroanatomy for almost 30 years before he retired and went a public contest becoming professor of the zoologist department, and then becoming professor of entomology at the same institution, a position in which he worked for more than 20 years, including as an emeritus professor after $2005^{1,6,7}$.

He worked broadly as a professor, neuroscientist, writer, dramaturgist, and entomologist but was never enchanted by bureaucratic positions ${ }^{3}$. In the neurobiology field, not only he was crucial for the knowledge regarding the involvement of the autonomous nervous system in animal models of Chagas disease, but also his time working as a professor of neuroanatomy was pivotal in the development of the book Neuroanatomia Funcional, launched in 1974, nowadays in its 3rd edition (2014), ${ }^{2,6}$. During his academic career, he substantially dedicated himself to the taxonomy of dragonflies ${ }^{7}$, the popularization of science, children's education, and nature conservation ${ }^{8}$.

\section{BOOKS}

Despite being less prominent than his wife in terms of neuroscientific curriculum, Professor Ângelo Machado was more embracing. His work as a professor of neuroanatomy associated with his great didactic and language skills was a landmark in the history of this field in Brazil. His students started collecting the knowledge that has been transmitted in his classes ${ }^{2}$. Soon, this material was gathered by the professor (Figure $2 \mathrm{~A}$ ), and he was strongly encouraged by his wife and friends to publish the first nationally published book about neuroanatomy ${ }^{2}$. Once the national book about the field was lacking, before starting as a professor, he moved away to the family farm to study English, French, and German books, preparing the entire content of his classes (personal communication - Figure 1B). He found slides too monotonous, and that is why he preferred to create his drawings on large panels to illustrate his lessons. His masterpiece is in charge of many medical students having chosen neurology or neurosurgery as a specialty to follow after graduating. The book is a practical guide for the anatomy course, with in-depth knowledge regarding structure, function, and anatomoclinical 

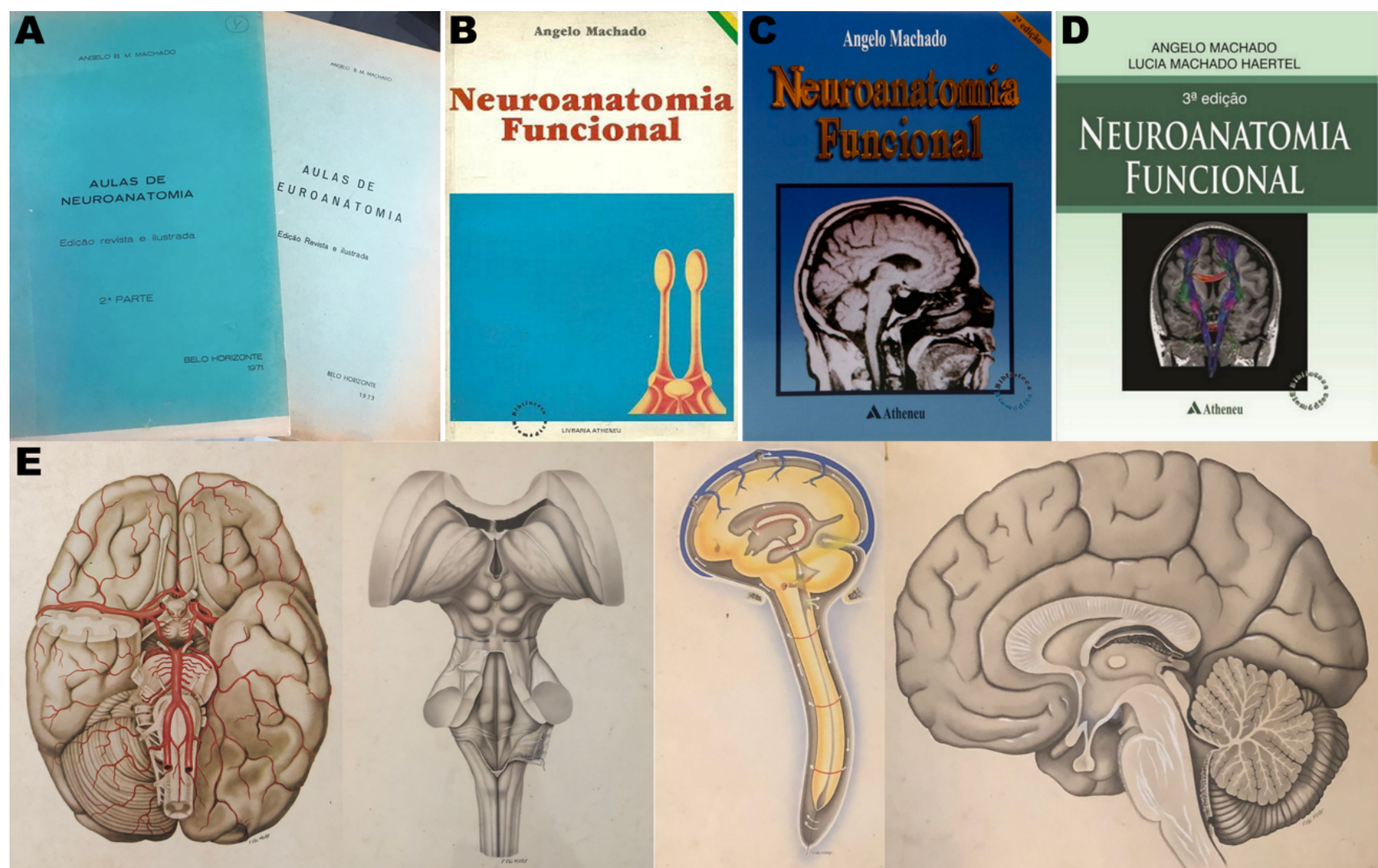

Figure 2. The handouts for the neuroanatomy course, which were later transformed into the book (A). Neuroanatomia Funcional, the pioneer and the standard reference book in National Medical Education for Neuroanatomy courses in several universities in Brazil: in its 1st edition, published in 1974 (B); 2nd edition, 2004 (C); and 3rd edition, 2015 (D); and some original drawings for the book, made by Val Moro, a designer from the Universidade Federal de Minas Gerais department (E).

correlations. It was first launched in 1974 (Figure 2B) and is still considered the standard reference for neuroanatomy courses in several universities in Brazil'. With the advances in the neurological field, mainly in the neuroimaging field, the 2nd edition was launched in 2004 (Figure 2C) ${ }^{10}$. In 2014, an entirely updated edition was published (Figure 2D), coauthored by his daughter Lúcia Machado Haertel, child neurologist, who was responsible for enriching the anatomical and clinical aspects of the book, making the study even more attractive, by correlating the morphofunctional aspects with the clinical practice ${ }^{11}$. Since the beginning, the designer Val Moro from the UFMG department was in charge of the illustrations (Figure $2 \mathrm{E}$ - original drawings) ${ }^{9}$. In 2021, the 4th edition of the book is expected, with improvements mainly in the anatomoclinical correlations (personal communication).

In 1987, he started a new field of knowledge: writing books in which he adapted scientific knowledge to children $^{12}$. He wrote 37 books for them and other 3 romances ${ }^{3}$. He was also a dramaturgist, with 6 plays for children and 2 comedies 4 . He received many National or State awards as follows: (1) the Jabuti award (Figure 1C), the most famous and important award of Brazilian literature, in 1993, for the book "O velho da montanha, uma aventura amazônica;" (2) the SESC-SATED award of the best children's play in
1996, for the play "O casamento da ararinha azul," which was also adapted as a short film; (3) and the highest grossing in 2001, for the comedy play "Como sobreviver em festas com buffet escasso". In 2017, he was awarded with the title of Emeritus researcher of the National Council of Scientific and Technological Development (CNPq), which is among 150 others awards and tributes, including the commendation of scientific merit and the Gram Cross of scientific merit delivered by the President of the Republic ${ }^{4}$.

The last book written by Prof. Machado was "Cristóvão e os grandes descobrimentos" in $2019^{13}$. Before his death, Prof. Ângelo Machado has been writing "Tratado de Guerra," a comic book for adults, concluded but unpublished, which will be done by his offsprings? Two things are certain as follows: his conservationism, environmentalism, and education will remain in our memories, and his book, Neuroanatomia Funcional, will continue encouraging and inspiring many medical students.

\section{ACKNOWLEDGMENT}

The authors thank the family Machado, in the names of Flávia Machado and Lúcia Machado Haertel, who cooperated incredibly with this article. 
1. Universidade Federal de Minas Gerais. 2021 [accessed on 2021 May 29]. Morre o professor, entomologista e escritor Ângelo Machado. Available from: https://ufmg.br/comunicacao/noticias/morre-oprofessor-entomologista-e-escritor-angelo-machado

2. Cardoso F. In memoriam Dr. Ângelo Machado. Arq Neuro-Psiquiatr. 2020 May;78(5):316-7. https://doi.org/10.1590/0004-282X20200049

3. Mitre M. Professor Angelo Machado: The remarkable deeds of a polyvalent mind. Lundiana. 2005;6(Supplement):5-10.

4. Marcolin N. Angelo Machado: Entre livros e libélulas. Pesq FAPESP. 2007;132:10-15. [accessed on 2021 Apr 7th, 2021]. Available from: https://revistapesquisa.fapesp.br/entre-livros-e-libelulas/

5. Machado AB, Machado CR, Wragg LE. Catecholamines and granular vesicles in adrenergic axons of the developing pineal body of the rat. Experientia. 1968 May;24(5):464-5. https://doi.org/10.1007/ bf02144394

6. Currículo do sistema Lattes. Angelo Barbosa Monteiro Machado. 17 may 2017 [accessed on 2021 May 29]. Available from: http:// lattes.cnpq.br/5343850000941639

7. Pinto AP. The dragonfly's face of the multidimensional Dr. Angelo Barbosa Monteiro Machado: a short bio-bibliography. Zootaxa. 2016 Feb;4078(1):8. https://doi.org/10.11646/zootaxa.4078.1.4
8. Nunes M. Ângelo Machado, cientista, escritor e "um grande líder da conservação da biodiversidade", morre aos 85 anos. [accessed on 2021 Apr 7th, 2021]. Available from: https://conexaoplaneta.com.br/ blog/angelo-machado-cientista-escritor-e-um-grande-lider-daconservacao-da-biodiversidade-morre-aos-85-anos/

9. Machado ABM. Neuroanatomia funcional. $1^{\text {st }}$ ed. São Paulo: Atheneu; 1974.

10. Machado ABM. Neuroanatomia funcional. $2^{\text {st }}$ ed. São Paulo: Atheneu; 2004.

11. Machado ABM, Haertel LM. Neuroanatomia funcional. $3^{\text {st }}$ ed. São Paulo: Atheneu; 2014.

12. Higashi AMF. Ciência e literatura em textos infantis de Angelo Machado [dissertation]. São Paulo: Universidade de São Paulo, Faculdade de Filosofia, Letras e Ciências Humanas; 2010 [accessed on 2021 May 29]. https://doi.org/10.11606/D.8.2010. tde-31012011-104437

13. Peixoto M. Ciência, arte e bom humor: conheça o imenso legado de Ângelo Machado [accessed on 2021 May 29]. Available from: https://www.em.com.br/app/noticia/cultura/2020/04/07/interna_ cultura,1136284/ciencia-arte-e-bom-humor-conheca-o-imensolegado-de-angelo-machado.shtml 